\title{
An Assessment of Constraints Faced by the Farmers in Peri-Urban Vegetable Cultivation
}

\author{
Jagriti Rohit $^{1^{*}}$, S. K. Dubey ${ }^{2}$, Premlata Singh ${ }^{3}$, B. K. Singh ${ }^{4}$ and N. V. Kumbhare ${ }^{5}$ \\ ${ }^{1}$ TOT, Section ICAR-CRIDA Santoshnagar Hyderabad-500059, Telangana, India \\ ${ }^{2}$ ICAR-ATARI, Kanpur, India \\ ${ }^{3}$ Division of Agricultural Extension, ICAR-Indian Agricultural Research Institute, \\ New Delhi, India \\ ${ }^{4}$ CATAT- ICAR-Indian Agricultural Research Institute, New Delhi, India \\ ${ }^{5}$ ATIC, ICAR-Indian Agricultural Research Institute, New Delhi, India \\ *Corresponding author
}

\begin{tabular}{|l|l|}
\hline \multicolumn{1}{l}{ A B S T R A C T } \\
\cline { 1 - 1 } $\begin{array}{l}\text { Keywords } \\
\begin{array}{l}\text { Ranking, Labour, } \\
\text { marketing, Peri- } \\
\text { urban, Vegetable } \\
\text { cultivation. }\end{array}\end{array}$ & $\begin{array}{l}\text { Identification of the key production constraints and provision environmentally- } \\
\text { sound options for agricultural resource management is necessary to increase } \\
\text { vegetable production in peri-urban farming communities. The data were collected } \\
\text { from a sample of 120 respondents of Hapur district of Uttar Pradesh state and } \\
\text { Faridabad district of Haryana stateto analyze the various constraints faced by the } \\
\text { farmers of peri urban agriculture. Garrett Ranking technique was used to rank the } \\
\text { constraints faced in peri-urban vegetable cultivation. Among the technological } \\
\text { constraints the most important constraint was unavailability of inputs including } \\
\text { fertilizers at the right time, and unavailability of labour at the harvest season was } \\
\text { the foremost among the labour constraints. Other constraints were related to } \\
\begin{array}{l}\text { Available Online: } \\
\text { 10 October 2017 }\end{array}\end{array}$ \\
\hline \hline
\end{tabular}

\section{Introduction}

Globally, has been a tremendous increase in the growth of urban population in the recent time. The situation in India is no different. Indian cities are home to an estimated 340 million people, almost equivalent to 30 per cent of the total population. As evident in majority of the industrialized countries, India is experiencing a shift over time from a largely rural and agrarian population residing in villages to urban, non-agriculture centre's (Kapoor, 2012). Vegetable cultivation has become highly commercialized. But still there is a wide gap between current production and potential productivity. Innovative agricultural technologies that can increase food security in the developing world while conserving environmental resources do exist; yet the global difficulty is getting the appropriate and timely information to farmers. Fruits and vegetables typically constitute an essential part of the daily diet in India and they are in great demand round the year from most sections of the population. The commercial value of fruits and vegetables in terms of direct consumption, processing as well as trade has risen substantially in recent years. 
Their economic importance has also increased and high labour intensity in the production of most fruits and vegetables production also makes them important from the employment angle as well (Sharma, 1991). Increase in area allocation under horticultural crops has often been suggested as a measure for agricultural diversification, increased employment and income.

The producers and the consumers often get a poor deal and the middlemen control the market, but do not add much value. There is also massive wastage, deterioration in quality as well as frequent mismatch between demand and supply both spatially and over time (Subbanarasiah, 1991). Since vegetables are perishable in nature, lack of efficient marketing system and appropriate infrastructure results in huge post-harvest losses. Further, non-availability of improved and good quality seeds reduces the profitability and increases production risk.

In urban and peri urban region, it is seen that unavailability of land is becoming an important issue. Even in cities where agricultural use of land has been accepted and formalized, farming is squeezed by the growth of the city boundaries for residential and commercial purposes. Water shortage is considered as serious problems in some locations. Lack of information about market demands, sudden shortages, and prices isalso a limiting factor for urban farmers. When the marketing chain is long, farmers become subject to greater price fluctuations

\section{Materials and Methods}

The study was conducted in Hapur block of Hapur district in UP and Faridabad block of Faridabad district in Haryana. These districts were purposively selected, as vegetables cultivation covers a large area in these districts. Two villages each from Hapur and
Faridabad blocks were selected purposively for the study. Thirty respondents were selected randomly from each village. Thus, a total of 120 respondents constitute the sample of the study from four villages. The constraints in practicing peri urban agriculture were enlisted from practicing farmers, agricultural scientists, and also from literature. Further, all the identified constraints were categorized into five groups: technological, economic, labour, marketing and environmental constraints. The reliability coefficient of the questionnaire was 0.87 . The respondents were given these constraints to rate them on a five point continuum fromvery severe, quite severe, severe,-not so severe, and least severe. The collected details were analyzed using the Garrett's Ranking technique.

Garrett's Ranking Technique was used to identify and rank the constraints.Garrett's ranking technique provides the change of orders of constraints and advantages into numerical scores. The prime advantage of this technique over simple frequency distribution is that the constraints are arranged based on their importance from the point of view of respondents. Hence the same number of respondents on two or more constraints may have been given different rank. Garrett's formula for converting ranks into percent was given by,

Percent position $=100 *\left(\mathrm{R}_{\mathrm{ij}}-0.5\right) / \mathrm{N}_{\mathrm{j}}$

Where,

$\mathrm{R}_{\mathrm{ij}}=$ rank given for $\mathrm{i}^{\text {th }}$ factor by $\mathrm{j}^{\text {th }}$ individual

$\mathrm{N}_{\mathrm{j}}=$ number of factors ranked by $\mathrm{j}^{\text {th }}$ individual

The per cent position of each rank was converted into scores referring to the table given by Garrett and Woodswordh (1969). For each factors, the scores of individual 
respondents were added together and divided by the total number of the respondents for whom scores were added. These mean scores for all the factors were arranged in descending order, ranks were given and most important factors were identified.

\section{Results and Discussion}

\section{Constraints faced by the farmers in} practicing peri urban agriculture

It is important to understand the constraints faced by the peri urban cultivators in order to increase their effectiveness and also to give suggestions to the policy makers. Constraints can give us the way we can plan our policy for betterment of the farmers. Here, Garrett's ranking technique was used to identify and rank the constraints. The prime advantage of this technique over simple frequency distribution is that the constraints are arranged based on their importance from the point of view of respondents. The constraints faced by the farmers are categorised as following different components.

\section{Technical constraints}

The data depicted in the table 1 revealed that unavailability of inputs including fertilizers, insecticides and pesticide at right time was the major technical constraint (Garrett score 65.33)faced by the cultivators in peri-urban agriculture. Availability of fertilizer at the proper time was of great concern to the people. Lack of suitable varieties (Garrett score 60.76) and difficulty in following the recommended practices (Garrett score 53.33) were ranked at second and third position respectively. According to view point of farmers, lack of extension support was also an important constraint in practicing peri-urban agriculture and it was ranked fourth with the score of 50.99. Among other technical constraints faced by the farmers were lack of knowledge about scientific cultivation, lack of storage facilities, and lack of availability of literature. Kang'ethe, et al., (2007) also reported that major constraints to urban agriculture were illegality and lack of access to input. Fertilizer unavailability at the time of application leads farmers to buy fertilizers at much higher rate.Singh (2007) pointed out that non availability of good quality seed was the major infrastructure constraints perceived by 81 per cent of the vegetable growers while lack of extension staff and technical guidance (69\%) was found to be the second most important infrastructural constraints.

\section{Labour constraints}

The data in table 2 reveals that non availability of labour during harvesting season was considered the most important constraint related to labour with the Garrett score of 51.93.Involvement of labour to other activities and programmes implemented by the government can be the reason for their unavailability (as perceived by the farmers). Nath and Biswas (2011) also reported in their study non availability of labour during peak period as most important production constraints in vegetable cultivation. Other important constraints related to the labour were high cost of labour (Garrett score 43.37) and lack of skilled labour availability in harvesting and processing (Garrett score 38.50) which were ranked at second and third position respectively.

\section{Economic constraint}

The data regarding economic constraints reported in table 3 revealed that among the economic constraints, high cost of, fertilizers and manures were the most severe constraints faced by the farmers and with the score of 54.23 and it was ranked one. High cost of plant protection chemical (Garrett score 51.14) was the next important constraint faced 
by the peri-urban farmers followed by unawareness of the credit facilities (Garrett score 48.85) and the lack of price policy by the government (Garrett score 39.73) were ranked fourth and fifth respectively. High costs of fertilizers accompanied by unavailability of fertilizers were causing much discomfort to the farmers.

\section{Marketing constraint}

The data reported in the table 4 revealed that highly perishable nature of product resulted in post-harvest loss with the score of 58.12 was the number one constraints among all marketing constraints followed by market and price fluctuation (Garrett score 55.53) and middlemen mal practices (Garrett score 55.07) were the most prominent constraints faced by the respondents. The problem perceived by the farmers were high transportation cost (Garrett score 46.60). Problems of transportation means (Garrett score 40.45) was responded least because of the infrastructure facilities such as wellconnected road and rail networks in the study area with market.

\section{Environmental constraints}

Environment is also posing some constraints to the farmers. The data related to the environmental constraints is depicted in the table 5. Among different environmental constraints faced by the farmers, attack by insects and pests was the most severe and was ranked one and heavy incidence of diseases was two with Garretts ranking score of 64.1 and 63.61 respectively.

Excessive soil erosion (Garrett score 56.13), poor drainage (Garrett score 49.02), highly fluctuating weather conditions (Garrett score 44.62), and low soil fertility (Garrett score 38.14 ) ranked subsequently by the farmers in peri-urban agriculture. Dima et al., (2002) conducted field study in Windhoek and Oshakati using a detailed questionnaire.

Table.1 Technical constraints faced by the farmers in practicing peri-urban agriculture

\begin{tabular}{|c|l|c|c|}
\hline No. & Constraints & $\begin{array}{l}\text { Garrett } \\
\text { Score }\end{array}$ & $\begin{array}{l}\text { Garretts } \\
\text { ranking }\end{array}$ \\
\hline 1. & $\begin{array}{l}\text { Unavailability of inputs including fertilizer, insecticides } \\
\text { and pesticide at right time }\end{array}$ & 65.33 & I \\
\hline 2. & Lack of suitable varieties & 60.76 & II \\
\hline 3. & \begin{tabular}{l} 
Difficulties in following the recommended practices \\
\hline 4.
\end{tabular} & $\begin{array}{l}\text { Lack of adequate extension support/ recommended } \\
\text { practices }\end{array}$ & 50.39 \\
\hline 5. & $\begin{array}{l}\text { Lack of knowledge about Scientific cultivation } \\
\text { technical guidance }\end{array}$ & 47.16 & IV \\
\hline 6 & Lack of storage facilities & 40.04 & VI \\
\hline 7 & Lack of availability of literature & 34.01 & VII \\
\hline
\end{tabular}


Table.2 Labour constraints faced by the farmers in practicing peri-urban agriculture

\begin{tabular}{|c|l|c|c|}
\hline No. & Constraints & $\begin{array}{l}\text { Garrett } \\
\text { Score }\end{array}$ & $\begin{array}{c}\text { Garrett } \\
\text { ranking }\end{array}$ \\
\hline 1. & Non-availability of labour during harvesting period & 51.93 & I \\
\hline 2. & High cost of labour & 43.37 & II \\
\hline 3. & $\begin{array}{l}\text { Lack of skilled labour availability in harvesting and } \\
\text { processing. }\end{array}$ & 38.50 & III \\
\hline
\end{tabular}

Table.3 Economic constraints faced by the farmers in practicing peri-urban agriculture

\begin{tabular}{|c|l|c|c|}
\hline No. & Constraints & $\begin{array}{c}\text { GarrettSc } \\
\text { ore }\end{array}$ & Garrett ranking \\
\hline 1. & High cost of fertilizers and manures & 54.23 & I \\
\hline 2. & High cost of plant protection chemicals & 51.14 & II \\
\hline 4. & Unawareness of credit facilities government & 48.45 & III \\
\hline 5. & Lack of price policy by government & 39.73 & IV \\
\hline
\end{tabular}

Table.4 Marketing Constraint faced by the farmers in practicing peri-urban agriculture

\begin{tabular}{|c|l|c|c|}
\hline No. & Constraints & Garrett Score & Garrett ranking \\
\hline 1. & Perishable nature of product & 58.125 & I \\
\hline 2 & Market and price fluctuation & 55.53 & II \\
\hline 3. & Middle man malpractices place & 55.07 & III \\
\hline 4. & Lower price at the harvesting stage place & 48.68 & IV \\
\hline 5. & High cost of transportation place & 46.40 & V \\
\hline 6. & Lack of marketing facilities at local place & 42.7 & VI \\
\hline 7. & Problems of transportation means & 40.45 & VII \\
\hline
\end{tabular}


Table.5 Environmental constraints faced by farmers in practicing peri-urban agriculture

\begin{tabular}{|c|l|c|c|}
\hline No. & Constraints & Garrett Score & Garrett ranking \\
\hline 1. & Attack by insects and pests & 64.1 & I \\
\hline 2. & Heavy incidence of diseases & 63.61 & II \\
\hline 3. & Excessive soil erosion & 56.13 & III \\
\hline 4. & Poor drainage & 49.01 & IV \\
\hline 5. & Highly fluctuating weather conditions & 44.62 & V \\
\hline 6. & Low soil fertility status & 38.14 & VI \\
\hline
\end{tabular}

$\mathrm{N}=120$

The result of the study showed that constraints in urban and peri urban included shortage of water $(41 \%, 51 \%)$ pests attacks $(40 \%, 38 \%)$, that theft of the produce $(31 \%$, 24\%) for Windhoek and Oshakati respectively.

It also revealed that other important problem that urban farmers were facing includes lack of information regarding the type of crops to grow, the chemicals to use and the prices, producers would receive for their products. This is partly because of the absence of Extension Services to the producers (Windhoek 64\% and Oshakati 70\%).

\section{Suggestions to overcome these constraints}

It was necessary to get the feedback of how farmers want these constraints to be sort out. So to understand the view point of the farmers, they were asked to give suggestions to overcome the above mentioned constraints. Following suggestions were suggested by the farmers to solve the constraints in peri urban agriculture.

Unavailability of input including fertilizer at the right time and also their high cost were one of the major constraints faced by the farmers. More government shops or centers should be opened to ensure adequate and timely supply of these inputs at fair price was suggested by the farmers.

Protected crop and nursery production technology should be popularized so as to make it profitable/viable on commercial scale. This will also help in off-season production of vegetables.

For proper irrigation of their crops, inadequate electricity supply was the major hindrance and the farmers wanted regular supply of electricity to overcome the problem of irrigation. Also sprinkler and drip irrigation need to be promoted by the government.

Most of the farmers suggested that procedure and official formalities for getting loan from the bank should be simplified. The bank can make it simple for farmers or it can deploy any person for specially helping the farmers.

Price fluctuation was the major source of dissatisfaction among most of the farmers and so they demanded better price for their produce and better marketing facilities. More of the regulated market should be established. Even minimum support price for vegetable need to be announced by the government for the benefit of the farmers. There is an urgent need of opening of local market units in their area so that they can directly sell the produce 
to these markets without suffering by middle men. Farmers demanded the subsidies and incentives by the government to overcome the high cost of planting materials and inputs.

To overcome the problem of perishable nature of the produce, infrastructural facilities for post-harvest management viz., cool transport chain, precooling units, packing houses, short- and long-term cold stores, etc., should be strengthen.

The government can also start with the crop insurance in case of perishable product also

Lack of extension support and difficulty in practicing the recommended technology was perceived as constraint by the farmers. To overcome these, proper demonstration of the new technologies should be made. The government can make village visit every week for the extension people would be strengthening market at local level.

Urban and peri-urban agriculture (UPA) plays an important rolein managing urban open spaces, provide employment and supply cheap food. The expansion and intensification of UPA production has also improved the livelihoods offarmers. Though peri urban agriculture has many benefits, there are several constraints which are coming in the way of farmers practicing peri-urban agriculture. From the results of analysis for different constraints, it was obvious that all the enlisted constraints were important in one way or the other. However, still those related to the technological aspects had a major role in creating obstacles to peri urban agriculture. Unavailability of inputs including fertilizers, insecticides and pesticides along with their high cost was perceived as major hurdle in peri-urban agriculture. The strategies listed above may be adopted by all the stakeholders in order to promote and support peri urban agriculture.

\section{References}

Dima, S. J., Ogunmokun A. A. and Nantanga. 2002. The status of urban and periurban agriculture, Windhoek and Oshakati, Namibia. ftp://ftp.fao.org/sd/sdww/nam_ periurban_02.pdf

Garrett, E. H., and Woodworth, R. S. 1969.Statsistics in psychology and education.Vakils, Feffer and Simons Pvt. Ltd., Bombay, pp -329.

Kang'ethe, E.K., Grace, D. and Randolph, T.F. 2007. Overview on urban and periurban agriculture: definition, impact on human health, constraints and policy issues. East African Medical Journal, 84(11):S48-56

Kapoor, R., 2012. Urban agriculture for food security. Business line, Oct.16

Nath, D., \& Biswas, P. K. 2011.Production Constraints of Vegetable Cultivation in West Tripura. Journal of Community Mobilization and Sustainable Development, 6(2), 177-179.

Sharma, K., 1991. Marketing Management of Horticulture Produce, Deep \& Deep, New Delhi.

Singh, D.K., 2007. Commercial vegetable cultivation on Ghaziabad district (U.P): An analytical study, unpublished. M.Sc. (Ag) Thesis, Division of agricultural extension, IARI, New Delhi.

Subbanarasaiah, N., 1991.Marketing of Horticultural Crops in India. Delhi, Anmol Publishing Co.

\section{How to cite this article:}

Jagriti Rohit, S.K. Dubey, Premlata Singh, B.K. Singh and Kumbhare, N.V. 2017. An Assessment of Constraints Faced by the Farmers in Peri-Urban Vegetable Cultivation. Int.J.Curr.Microbiol.App.Sci. 6(10): 2245-2251. doi: https://doi.org/10.20546/ijcmas.2017.610.265 